\title{
Effect of the Online Transportation against Conventional Transportation and User of Transportation Services in Semarang Poncol Railway Station, Indonesia (Legal and Economic Perspective)
}

\author{
Kholidah Romli ${ }^{1 \mathrm{a}}$, Shania Correlly Noor' Sabila ${ }^{\mathrm{lb}}$, Farhan Hamka Ilyasa ${ }^{\text {1c }}$ \\ ${ }^{1}$ Students at Faculty of Law, Universitas Negeri Semarang (UNNES), Indonesia \\ ${ }^{\mathrm{c}}$ farhan.ilyasa@gmail.com
}

\begin{abstract}
At this time, public transport is something that cannot be separated from everyone. Public vehicles that have very important components, as well as in development, as well as the center of the economic movement in the city. One of the most effective and efficient public facilities is motorcycle taxi. Ojek people by residents in big cities because of its advantages, that is faster and can pass through the congestion in the city. Usually a motorcycle taxi is available at a crowded intersection, or in a residential area entrance. The more rapid technology of the era, making a lot of people used to innovate, one of which is the use of Internet technology in the field of transportation. Indonesia has an online service that allows candidates not to come to an ojek base. Potential passengers simply order motorcycles from an app on a smartphone, and the motorcycle taxi will come pick up. However, in its development often occurs friction between online transport with conventional transportation. In this journal will be discussed various things that also provide an overview and advantages of each mode of transportation.
\end{abstract}

Keywords—online transportation; conventional transportation, legal and economic perspective

\section{INTRODUCTION}

One of the most effective and efficient public transport is the Ojek. Ojek or ojeg is an informal public transportation in Indonesia in the form of motorcycles. Called informal because its existence is not recognized by the government and there is no permission to operate it. Passengers are usually only one person. Ojek is widely used by residents in big cities because of its advantages with other transport, which is faster and can pass through the jam in the city. Usually a Ojek is available at a busy junction, or in the entrance to a residential area. Laws are not legally specified in Undang-Undang Nomor 22 Tahun 2009 tentang Lalu Lintas dan Angkutan Jalan, this Rules is expected to help organize and coordinate public transport and motorists on the road to be more orderly.

These public transportation act as the carrier of people and / or goods to facilitate the community in doing their activities. Discussion on the development of the legal aspects of transportation cannot be separated from the effectiveness of the transport law itself. The more rapid technology of the era, making a lot of people use it to innovate, one of which is the use of Internet technology in the field of transportation. Indonesia has an online motorcycle service that allows prospective passengers not to come to an ojek base. Ojek online itself booming began in 2014 because of easy access and cheap tariff given for using GPS-based technology to determine the tariff rather than the conventional motorcycle taxi that fix rates that are not in accordance with the distance traveled. The presence of ojek online is certainly triggered the reaction from various walks of life who rely on life with ojek service, the reaction will eventually lead to business conflicts between motorcycles conventional with ojek online.

\section{RESEARCH METHOD}

The research method used in this research is the sociological juridical approach. The sociological juridical approach is to identify and conceptualize law as a real and functional social entity in the real life system. The sociological juridical approach is to emphasize research that aims to gain legal knowledge empirically by plunging directly into the object of knowing the positive and negative impacts of the emergence of online transport of conventional transportation at Semarang Poncol Station. The statute approach is conducted by reviewing all laws or regulations related to legal issues to be investigated, ie research contained in Law No. 22 of 2009 on traffic and road transport (Undang-Undang Nomor 22 Tahun 2009 tentang Lalu Lintas dan Angkutan Jalan). 


\section{RESULT AND DISCUSSION}

The Ojek Online company was founded by one of the ojek drivers, Nadiem Makariem. With one of his friends, he learned that the leisure time of a Ojek driver was used only to sit waiting for passengers to arrive. It is very unfortunate if a lot of time is wasted just to wait for a passenger. Therefore Nadiem began thinking and decided to create an application such as social media, which can be used by Ojek drivers to facilitate customers to place an order online. In 2011 Nadiem managed to create a company and online application called Go-Jek. The cost incurred to get this service is also quite cheap. For a distance of 1 - $10 \mathrm{~km}$, charged about Rp. 12.000, distance 11 - $15 \mathrm{~km}$ Rp. 15,000, and a distance above $15 \mathrm{~km}$ is charged Rp. 2,000 / km.

Consistency Ojek Online in the application of this efficient communication technology to address social problems and public concerns about public transport, especially in the capital region. With the providers of online transportation services proved to provide solutions for congestion that occurred in the Greater Jakarta area and provide convenience and convenience for consumers. The advantages of GoJek that comes with an application that is connected with data base storage and GPS can provide information about the identity of the driver. With these advantages, people will easily find out who will be the driver of the transportation Ojek order, complete with the driver's own data concerned. Completeness of the data and identity of the drivers in the GoJek application is proof that Ojek Online is putting forward the security factor for its consumers. Inside the application is available complete information about the rider like the name, contact, and photo rider. This Online Ojek Service can only be obtained through reservations via the GoJek app, so customers can ensure their security and accountability.

A legitimate Online Ojek is not yet established in Law Number 22 Year 2009 on Road Traffic and Transportation is expected to help organize and coordinate public transports and motorists on the road to be more orderly. These public transportation act as the carrier of people and / or goods to facilitate the community in doing their activities. Discussion on the development of the legal aspects of transportation cannot be separated from the effectiveness of the transport law itself. Transportation in Indonesia is regulated in the Civil Code on the Third Book of Engagement, then in the Trade Code in Book II of title to $\mathrm{V}$. In addition, the government has issued a policy in the field of land transportation namely the issuance of Law no. 22 of 2009 on Traffic and Road Transport as a Substitute for Law no. 14 of 1992, and Government Regulation no. 41 of 1993 on Road Transportation.

\section{CONCLUSION}

Governments need to provide equal treatment to transport providers, with the orientation of protection to the community, including the protection of the people to earn a living and run the work. Currently the two authorities on this Online Ojek are located in two different ministries, for the transportation aspect is in the Ministry of Transportation while for the technological aspect of its application is in the Ministry of Communications and Informatics. In the future, the regulation on the Ojek Online can be effective, so the Ministry of Transportation must be provided with the authority to block if there are serious and repeated violations of service standards, because the Ministry of Transportation can evaluate whether the safety standard of transportation has been implemented by the company. For that government as a regulator must start preparing rules that can accommodate various services or services based on communication and information technology, such as this Online Motorcycle. On the other hand, the high demand of the public on Ojek Online encourages the government to apply consumer tax on users of Ojek Online so as to enlarge the income of the State.

\section{REFERENCES}

[1] Engel, J.F. et.al. 1994, Consumer Behavior Jilid 1, Alih Bahasa Budiyanto. Jakarta : Binarupa Aksara.

[2] Majid, Nurkholis. 2013. Tinjauan Yuridis Ojek Online, Jurnal Universitas Udayana. 3(1) 2.

[3] Marzuki, Peter Mahmud. 2013. Penelitian Hukum. Jakarta: PT. Kencana Prenada Media Group.

[4] Prihatin, Rohani Budi. 2016. "Dampak Sosial Transportasi Berbasis Online". Majalah Info Singkat: Kesejahteraan Sosial. 8(7): 9-11

[5] Rusli, Hardihan. 2006. "Metode Penelitian Hukum Normatif'. Law Review Fakultas Hukum Universitas Pelita Harapan, 3(1) 1.

[6] Soekanto, Soerjono. 1986. Pengantar Penelitian Hukum. Jakarta: Penerbit Universitas Indonesia Press.

[7] Susantono, Bambang. 2014. Revolusi Transportasi. Jakarta: PT. Gramedia Pustaka Utama.

[8] Wahda, Muhammad Jurnal, Tri Listyorini, Rizkysari Meimaharani, 2017 “ 3D Hologram Pengenalan Alat Transportasi ". Jurnal Universitas Muria Kudus. 8(1). 1.

[9] Waluya, Bagja. 2007. Sosiologi : Menyelami Fenomena Sosial di Masyarakat. Jakarta: PT. Grafindo Media Pratama.

[10] Waluyo, Bambang. 2002. Penelitian Hukum dalam Praktek. Jakarta: Sinar Grafika. 